\title{
Holsteins in Puerto Rico: III. Components of Variance Associated with Production Traits and Estimates of Heritability ${ }^{1}$
}

\author{
J. K. Camoens, R. E. McDowell, L. D. VanVleck, and \\ J. D. Rivera Anaya ${ }^{2}$
}

\begin{abstract}
Variance components were estimated for herd, sire, and cow effects with a three-way nested model, using unadjusted and adjusted records for age and seasonal difference from 62 herds on DHIA recording in Puerto Rico. The cows calved from 1967 to 1973 . They were high grade and purebred Holsteins imported from Canada or the United States or progeny of bulls and semen from the two countries. The percentages of the total variance for milk yield were $18.7,4.9$, and $40.8 \%$ for herd, sire, and cow, respectively. The percentages for fat yield were similar. These, plus the component for lactation length and days open, were in the range reported from temperate regions. The variance components of fat percent were similar to that of temperate regions for herd (14.9\%) and cow $(54.1 \%)$, but the sire component was negative, indicating factors yet unidentified that influenced this trait. Total variances for milk and fat yields indicated sufficient variability to permit selection.

Estimates of heritability and repeatability for milk yield, fat yield, fat percent, lactation length, and days open computed from the sire and cow variance components were consistent with those reported from the temperate regions. The estimates indicate there was no loss of genotypic variance in the tropical environment. It appears that genotype exerts as much influence on production in Puerto Rico as elsewhere.
\end{abstract}

\section{INTRODUCTION}

There have been a number of studies on estimates of variance associated with herd, sire, cow, and the total variance using data on Holsteins from temperate areas, but few such estimates are available from tropical areas. The estimates from tropical data have been based on

${ }^{1}$ Manuscript submitted to Editorial Board June 3, 1975.

${ }^{2}$ Veterinary Officer, Kuantan, Pahang, West Malaysia; Professor, Department of Animal Science, Cornell University, Ithaca, N.Y. and Consultant, University of Puerto Rico, Mayagüez and Río Piedras, P.R.; Professor, Department of Animal Science, Cornell University, Ithaca, N.Y.; and former Director of Department of Animal Husbandry, Agricultural Experiment Station, University of Puerto Rico, Río Piedras, P.R. The authors are grateful to the staff of the Animal Improvement Programs Laboratory, USDA, Beltsville, Md., and to Puerto Rico DHIA officers, for making the DHIA records available. 
single herds and breeds other than Holstein. This is mainly because of lack of data, especially from commercial herds in tropical areas. Estimates for heritability and repeatability of performance traits are likewise unavailable for Holsteins in tropical areas.

The objective of this study was to utilize data from a tropical area, Puerto Rico, for determining the variance in several traits associated with herd, sire, cow, and the total variance, as well as estimates of heritability and repeatability.

\section{PROCEDURE}

The data came from herds on DHIA recording in Puerto Rico and consisted of 33,950 records from 62 herds for cows calving from 1967 to 1973. Further description of the data and screening procedures are found in another report (7). For the present study the following restrictions were applied: 1) Only normally terminated records were accepted; 2) all records exceeding 305 days were excluded, as were records of less than 60 days duration; 3) only records with cow and sire identification were considered; and 4) milk and fat records were adjusted for age-season effects with factors derived from Puerto Rico data (6).

The model used for estimating components of variance of each trait was:

$$
Y_{i j k l}=\mu+H_{i}+S_{i j}+C_{i j k}+\mathrm{e}_{i j k l}
$$

where,

$Y_{i j k l}=$ the measurement of a trait of interest;

$\mu \quad=$ the population mean common to all records;

$H_{i}=$ the random effect associated with the $i$ th herd with mean zero and variance $\sigma_{h}{ }^{2}$;

$S_{i j}=$ the random effect of the $j$ th sire nested in the $i$ th herd with mean zero and variance $\sigma_{s}{ }^{2}$;

$C_{i j k}=$ the random effect of the $k$ th cow nested within the $j$ th sire in the $i$ th herd with mean zero and variance $\sigma_{c}{ }^{2}$;

$e_{i j k l}=$ random error with mean zero and variance $\sigma_{e}{ }^{2}$.

The model assumed the effects of herds, sires, cows, and the error term were random (26). The estimation of variance components for an unbalanced hierarchal design has been described by Gates and Shiue (17) and Gower (18).

The estimates of the components of variances were denoted as $\sigma_{h}{ }^{2}, \sigma_{s}{ }^{2}$, $\sigma_{c}{ }^{2}$, and $\sigma_{e}{ }^{2}$; and $\sigma_{p}{ }^{2}$ was the sum of these or estimated total variance. Heritabilities were estimated across herds (overall) as $4 \sigma_{s}{ }^{2} / \sigma_{p}{ }^{2}$ and within herd as $4 \sigma_{s}{ }^{2} /\left(\sigma_{p}{ }^{2}-\sigma_{h}{ }^{2}\right)$. Similarly, repeatabilities overall were estimated as $\left(\sigma_{s}{ }^{2}+\sigma_{c}{ }^{2}\right) / \sigma_{p}{ }^{2}$ and within herd as $\left(\sigma_{s}{ }^{2}+\sigma_{c}{ }^{2}\right) /\left(\sigma_{p}{ }^{2}-\sigma_{h}{ }^{2}\right)$. 


\section{RESULTS AND DISCUSSION}

\section{COMPONENTS OF VARIANCE}

The component of variance for herd $\left(\sigma_{h}{ }^{2}\right)$ appeared important for milk yield, fat yield, and fat percent, using either the unadjusted or adjusted records (table 1). It was smaller for length of lactation and of little consequence for days open. The relative variation between herds was less than generally reported from temperate regions. Most estimates range from 30 to $40 \%$ for milk and fat yields and fat percent $(1,4,9,13,27,29)$. However, the estimated variance for the three traits made by Cunningham (11) was similar to the estimates for Puerto Rico. The differences among estimates are partially due to the models employed. In several studies, e.g., VanVleck and Henderson (29), variance for cows and herds were not separated, thereby probably resulting in some inflation in $\sigma_{h}{ }^{2}$.

TABLE 1.-Estimated percentages of variance for herd, sire, cow, and error and the total variance for several traits

\begin{tabular}{lccccc}
\hline \multicolumn{1}{c}{ Trait } & Herd & Sire & Cow & Error & Total \\
\hline \multicolumn{5}{c}{$\%$} \\
Milk yield & 18.7 & 4.9 & 40.8 & 30.5 & $16,452,663\left(\mathrm{lb}^{2}\right)$ \\
Fat yield & 20.5 & 4.7 & 38.9 & 36.0 & $21,927\left(\mathrm{lb}^{2}\right)$ \\
Fat percent & 14.9 & -19.9 & 54.1 & 50.9 & $.1426\left(\%{ }^{2}\right)$ \\
Lactation length & 8.6 & -18.8 & 59.9 & 50.2 & $3,839\left(\right.$ days $\left.^{2}\right)$ \\
Days open & 1.9 & -19.9 & 57.3 & 61.1 & $6,731\left(\right.$ days $\left.^{2}\right)$ \\
& After & Age-Season Adjustment & \\
Milk yield & 18.7 & 2.0 & 42.5 & 36.8 & $16,061,914\left(\mathrm{lb}^{2}\right)$ \\
Fat yield & 20.4 & 2.0 & 40.5 & 37.1 & $21,771\left(\mathrm{lb}^{2}\right)$ \\
Fat percent & 14.8 & -19.0 & 53.8 & 50.2 & $.1450\left(\%{ }^{2}\right)$ \\
\hline
\end{tabular}

Also, when cows with only a single record are included, the cow variance goes into the $\sigma_{e}{ }^{2}$ component which will reduce the relative size $\sigma_{h}{ }^{2}$. In the present study cow variance was separated and only cows with repeat records included.

The estimated $\sigma_{h}{ }^{2}$ for days open (table 1) agrees with reports from temperate regions. For instance, Dunbar and Henderson (12) estimated that $\sigma_{h}{ }^{2}$ for nonreturns was essentially zero.

The sire component $\left(\sigma_{s}{ }^{2}\right)$ for milk and fat yield was about $5 \%$ of the total variation. These values are in the lower range of estimates ( 3 to $10 \%)$ that have been reported $(4,11,13,21,29)$.

The $\sigma_{s}^{2}$ for fat percent, lactation length, and days open were negative (table 1). These were interpreted to mean that sire variance was zero, that is to say, genotype contributed no detectable part in the expression 
of these traits in Puerto Rico herds. Estimates of zero for $\sigma_{s}{ }^{2}$ in percent fat have also been reported from the United States $(10,11)$. Higher estimates have been reported $(1,4)$, and the heritability is accepted at about 0.50 . Estimates of $\sigma_{s}{ }^{2}$ that approach zero for lactation length and days open are generally accepted $(11,24,25)$.

By far the largest component of variance was $\sigma_{c}{ }^{2}$, the variance among cows (table 1). Near $40 \%$ of the variation in milk and fat, over $50 \%$ of that in fat percent, and about $60 \%$ of the variation in lactation length and days open were attributed to differences between cows. The magnitude of the estimates indicates a sizeable potential for cow selection and/or changes in herd management to improve both production and reproduction in Puerto Rico.

The elements of the model-herds, sires, and cows-accounted for more than $60 \%$ of the variation in milk and fat yields. The error, or unexplained variance, with 30 to $36 \%$ which is somewhat lower than the estimates of 48 to $50 \%$ obtained by others $(21,29)$. The difference in results was attributed to the more extensive model used in the present study. The $\sigma_{e}{ }^{2}$ for fat percent was $50.2 \%$ of the total variance. The conclusion is that factors unidentified in this study influenced the error component for fat percent. In previous reports $(7,8)$ it was pointed out that fat percent varies from the expected in Puerto Rico. The error component for lactation length and days open is not different from that reported from cooler climates, especially for days open (12).

After adjusting milk and fat yields for age and season of calving, the total variation decreased about $2.4 \%$ for milk and $0.7 \%$ for fat yield. Changes in the total variation for fat percent were negligible. The differences suggest that age and season could account for these approximate percentages in total variation for milk and fat. The adjustment for age and season brought little change in the estimates of $\sigma_{h}{ }^{2},{\sigma_{c}}^{2}$, or $\sigma_{e}{ }^{2}$ for milk yield; however, $\sigma_{s}{ }^{2}$ decreased to about half when unadjusted records were used. This suggests some confounding of sires and ages.

The total variance for milk yield (table 1) was more than twice that for herds in New York $(20,29)$. In the New York studies only 305-day, 2X, mature equivalent records were used while the Puerto Rico data included records of 60 to 305 days. While the greater variance could have resulted because of the confounding effect of lactation length, it is apparent that sufficient variability is available in the dairy cattle of Puerto Rico for improvement through selection.

An important practical conclusion derived from the components of variance is that considerable change could be achieved in Puerto Rico herds by improving herd environments, selecting good sires, and giving more attention to culling of cows. 


\section{HERITABILITY AND REPEATABILITY}

Heritability and repeatability estimates derived from the components of variance are in table 2 . The estimates of heritability for milk and fat yields with unadjusted records are similar to those for Holsteins in temperate areas $(2,3,5,11,15,19,30)$, but lower than some other estimates $(10,23)$.

Since the estimated components for sire variance of fat percent, lactation length, and days open were negative (table 1) and assumed to be zero, heritability estimates for these traits were zero. The low heritability for lactation length and days open agrees with most other studies, but the generally accepted heritability for fat percent ranges from 50 to $60 \%$ (22).

The estimates of repeatability for all traits (table 2) are similar to currently accepted values (22).

TABLE 2.-Estimated heritability and repeatability for various traits

\begin{tabular}{|c|c|c|c|c|}
\hline & \multicolumn{2}{|c|}{ Heritability } & \multicolumn{2}{|c|}{ Repeatability } \\
\hline & Overall & Within herd & Overall & Within herd \\
\hline & \multicolumn{4}{|c|}{$\%$} \\
\hline & \multicolumn{4}{|c|}{ Unadjusted Records } \\
\hline Milk yield & 19.5 & 24.0 & 45.7 & 56.3 \\
\hline Fat yield & 18.6 & 23.4 & $4: 5$ & 54.7 \\
\hline Fat percent & 0 & 0 & 34.2 & 40.1 \\
\hline Lactation length & 0 & 0 & 50.5 & 54.4 \\
\hline \multirow[t]{2}{*}{ Days open } & 0 & 0 & 47.6 & 48.4 \\
\hline & \multicolumn{4}{|c|}{ After Age-Season Adjustment } \\
\hline Milk yield & 7.9 & 9.7 & 44.5 & 54.7 \\
\hline Fat yield & 7.9 & 9.9 & 42.5 & 53.3 \\
\hline Fat percent & 0 & 0 & 54.1 & 63.4 \\
\hline
\end{tabular}

The heritability estimates derived for milk yield and fat yield using adjusted records are much lower than expected (table 2). The cause or causes for the marked reduction in estimates without appreciable changes in the repeatability estimates is not clear at this time.

An interesting aspect emerging from this study of variance components, heritability, and repeatability is the performance of an imported genotype in a tropical environment. In Puerto Rico a number of the cows were imported from Canada or the United States, and most of the others were progeny of either semen imported or bulls purchased from the two countries for use in the local AI center or natural services on some farms. Heretofore, it has been assumed that much of the genetic variation would be overridden by the tropical environment (14). The present study does 
not support this hypothesis. The highest producing cows in Puerto Rico have been high grade or purebred Holsteins (16). Other breeds, such as native, crossbred, and Brown Swiss, that were tried earlier, at present represent less than $10 \%$ of the total dairy cow population. The components of variance are well within the range accepted for temperate regions. VanVleck (28) indicated genetic variability could differ from one environment to another. He concluded that higher levels of production were associated with higher genetic variability. Lower estimates of genetic variability could, therefore, be a function of lower levels of production. The obvious conclusion is that even in the tropics, if high levels of production could be attained, higher estimates of genetic variability would result. Nonetheless, it appears that even though levels of feeding and management in Puerto Rico may not be sufficient for full expression of genetic potential for milk production, the use of good genetic stock is warranted.

\section{RESUMEN}

Se estimaron los componentes de variación para los efectos de hato, toros y vacas usando un modelo en diseño factorial. Se usaron los registros no ajustados y los adjustados para edad y la estación del año de 62 hatos inscritos en la asociación de mejoramiento de hatos lecheros de Puerto Rico. Las vacas, que parieron del 1967 al 1973, eran Holstein puras o de alto grado de pureza importadas del Canadá o de los Estados Unidos o progenie de toros y semen de los dos paíes. Los porcentajes de la variación total para la producción de leche fueron 18.7, 4.9 y 40.8 para hato, toro y vaca, respectivamente. Los porcentajes de producción de grasa fueron similares. Estos, más el componente de duración de la lactación y días receptivos, estaban en los límites informados para zonas templadas. Los componentes de variación del porcentaje de grasa fueron similares a los de zonas templadas para hato $(14.9 \%)$ y vaca $(54.1 \%)$. El componente toro fue negativo, indicando que factores todavía no identificados afectaron este rasgo. Las variaciones totales para la producción de leche y grasa indicaron que había suficiente variabilidad para permitir la selección.

Los estimados de la hereditabilidad para la producción de leche y grasa, contenido de grasa, duración de la lactación, y días receptivos computados de los componentes de variación para toro y vaca fueron consistentes con los informados en las zonas templadas. Los estimados indican que no hubo pérdida de la variación genotípica en el ambiente tropical. Se puede concluir que el genotipo parece ejercer tanta influencia en la producción de leche en Puerto Rico como en cualquiera otra parte. 


\section{LITERATURE CITED}

1. Allaire, F. R., First lactation contemporary comparisons as indicators of environmental influences on daughter records used for sire evaluation, M.S. Diss. Univ. Mass., Amherst, 1963.

2. Bar-Anan, R., Breeding the Israeli-Friesians, Tel-Aviv Ext. Serv., Min. Agr., Israel (Mimeo.), 1971.

3. Bereskin, B., and Freeman, A. E., Genetic and environmental factors in dairy sire evaluation. I. Effects of herd, months and year-seasons of variance among lactation records; repeatability and heritability, J. Dairy Sci., 48: 347-51, 1965.

4. Burdick, J. M., and McGilliard, L. D., Interactions between sires in artificial insemination and management of dairy herds, J. Dairy Sci., 46: 452-8, 1963.

5. Butcher, K. R., Sargent, F. D., and Legates, J. E., Estimates of genetic parameters for milk constituents and yields, J. Dairy Sci., 50: 185-93, 1967.

6. Camoens, J. K., McDowell, R. E., VanVleck, L. D., Drosdoff, M., Miller, P. D., Ufford, G. R., and Rivera Anaya, J. D., Factores para ajustar los registros de producción de vacas Holstein en Puerto Rico según la edad del animal y el mes de nacimiento, Est. Exp. Agr., Univ. P.R., Pub. (99), 1976.

7. —_- , and Rivera Anaya, J. D., Holsteins in Puerto Rico: I. Influence of herd, year, age, and season on performance, J. Agr. Univ. P.R. 60(4): 526-39, 1976.

8. - - - - - - Holsteins in Puerto Rico. II. Influence of lactation length, days dry, days open, and calving interval on production traits, J. Agr. Univ. P.R. 60(4): $540-50,1976$.

9. Castle, O. M., and Searle, S. R., Repeatability of dairy cow butter fat records in New Zealand, J. Dairy Sci., 40: 1277-83, 1957.

10. Clark, R. D., and Touchberry, R. W., Effect of body weight and age at calving on milk production in Holstein cattle, J. Dairy Sci., 45: 1500-10, 1972.

11. Cunningham, E. P., Components of variation in dairy cattle production records, Ire. J. Agr. Res., 11: 1-10, 1972.

12. Dunbar, R. S., Jr., and Henderson, C. R., Heritability of fertility in dairy cattle, J. Dairy Sci., 36: 1063-71, 1953.

13. Fairchild, T. P., Tyler, W. J., Barr, G. E., and Corley, E. L., Estimating transmitting abilities of artificial insemination sires, J. Dairy Sci., 49: 1416-25, 1966.

14. Falconer, D. S., An introduction to quantitative genetics, Ronald Pub. Co., N.Y., 1960.

15. Freeman, A. E., Estimates of genotype by environment interaction and effects of contemporaneity upon growth and production from cattle twins, j. Dairy Sci., 52: 926, 1969.

16. Gaztambide, C., Aclimatación, cuido y manejo del ganado lechero en los trópicos, C. Gaztambide, Calle Hoare Núm. 705, Santurce, P.R.

17. Gates, C. E., and Shiue, C., The analysis of variance of the S-stage hierarchal classification, Biometrics, 18: 529-36, 1962.

18. Gower, J. C., Variance component estimation for unbalanced hierarchal classifications, Biometrics, 18: 537-42, 1962.

19. Hickman, C. G., and Henderson, C. R., Components of the relationship between levels of production and rate of maturity of dairy cattle, J. Dairy Sci., 38: 883-90, 1955.

20. Hillers, J. K., and Everson, D. O., Effects of various discrete distributions on magnitude of heritability, J. Dairy Sci., 55: 682, 1972.

21. Hooven, N. W., Miller, R. H., and Plowman, R. D., Genetic and environmental relationships among efficiency, yield, composition, and weight of Holstein cows, J. Dairy Sci., 51: 1409-19, 1968. 
22. McDowell, R. E., Improvement of livestock production in warm climates, W. H. Freeman \& Co., San Franciso, 1972.

23. Norman, H. D., McDaniel, B. T., and Dickinson, F. N., Conflicts between heritability estimates of mature equivalent and herdmate-deviation milk and fat, J. Dairy Sci., 55: 507-17, 1972.

24. Schaeffer, L. R., Everett, R. W., and Henderson, C. R., Lactation records adjusted for days open, J Dairy Sci., 56: 602-7, 1973.

25. — and Henderson, C. R., Effects of days dry and days open on Holstein milk production, J. Dairy Sci., 55: 107-12, 1972.

26. Searle, S. R., Linear models, Wiley \& Sons, N.Y., 1971.

27. Spalding, R. W., Henderson, C. R., Carter, H. W., Albrectsen, R., and Meek, A. M., The selection and evaluation of dairy sires, N.Y. State Coll. Agr. Ext. Bull. 1118, Ithaca, 1963.

28. VanVleck, L. D., Genotype and environment in sire evaluation, J. Dairy Sci., 46: 983-7, 1963.

29. — , and Henderson, C. R., Measurement of genetic trend, J. Dairy Sci., 44: 1073-84, 1961.

30. Wilcox, C. J., Heritabilities and genetic correlations of milk composition and yield, J. Dairy Sci., 49: 734, 1966. 